\title{
La isla desierta de Roberto Arlt: una contertulia con el teatro de la crueldad de Antonin Artaud en la caverna de Platón/
}

\author{
Roberto Arlt's The desert island: a conversation with Antonin \\ Artaud's theatre of cruelty in Plato's cavern
}

\author{
Spyros Mavridis
}

Universidad Abierta de Grecia

El artículo explora las convergencias entre el teatro de la crueldad de Antonin Artaud y la búsqueda paralela de Roberto Arlt en el caso concreto de su obra La isla desierta. Se apuntan las influencias rastreables en esta pieza y se señala su inspiración como originada en el símil de la caverna de Platón. Asimismo, se realiza una síntesis de estos dos proyectos teatrales, donde se exponen las afinidades, como también las diferencias entre las dos versiones de la crueldad.

Palabras Clave: Teatro (Género literario); Teatro argentino; Teatro hispanoamericano; Arlt, Roberto, 1900-1942; Artaud, Antonin, 1896-1948; Teatro de la crueldad; Historia del teatro: Literatura hispanoamericana; La isla desierta; Teatro experimental; Drama Siglo XX; Teatro francés.

The article explores the convergences between the theatre of cruelty of Antonin Artaud and the parallel search of Roberto Arlt's specific case of his work The desert island. It indicates the traceable influences in this piece and highlights its inspiration as it originates from Plato's Allegory of the Cave. Furthermore, a synthesis of these two theatrical projects is performed where both simalirities and differences of the two versions of cruelty are presented.

KEYwORDS: Theatre; Argentinean Theatre; Latin-American drama; Arlt, Roberto, 1900-1942; Artaud, Antonin, 1896-1948; Theatre of Cruelty; Theatre history; Latin-American Literature; The desert island; Experimental drama; Drama-20th Century; French drama. 
Después del traspié de El fabricante de fantasmas (1936) y su aventura fallida en el teatro institucionalizado, Roberto Arlt decidió volver a los círculos del Teatro del Pueblo para insistir en una estética "marginal" e independiente con su pieza La isla desierta (1937), calificada por el mismo dramaturgo como burlería en un acto.

Respecto a intertextualidades con la literatura universal, esta pieza parece de las menos «contagiadas» de la producción teatral arltiana por este tipo de deudas, salvo las correspondencias que mantiene con la alegoría de la caverna platónica. Su estética se ha calificado como expresionista ${ }^{1}$ con ribetes del grotesco colectivo ${ }^{2}$ que estigmatiza el hipertecnicismo de las sociedades modernas mediante la imagen del hombre-autómata. No obstante, como analizaremos en el presente artículo, podemos rastrear en esta obra semillas de inquietudes paralelas a las de la poética de la crueldad de Antonin Artaud.

Arlt, artista inquieto y perspicaz, cosechó los elementos más fructíferos de los proyectos de los dramaturgos de la vanguardia y estructuró su modelo teatral partiendo del meta-teatro de Luigi Pirandello y «tentado» por la «crueldad» de Artaud. Y si la intertextualidad entre la dramaturgia de Pirandello y la de Arlt está bien estudiada y comprobada, la afinidad estética con el teatro de la crueldad y la utopía teatral que tanto Artaud como Arlt perseguían partiendo de caminos distintos, apenas ha sido abordada por la bibliografía. Aunque las diferencias entre los proyectos de Arlt y Artaud son suficientes como para que no nos aventuremos a identificarlos, existen también bastantes indicios como para sostener que parten de los mismos principios hacia la misma meta. Afirmación también válida para esta pequeña perla teatral que constituye $L a$ isla desierta.

\section{Argumento}

El argumento de la obra concierne a un grupo de trabajadores en una oficina de la zona portuaria de Buenos Aires, donde, pese a la proximidad de los buques y los mares que ellos reclaman, los oficinistas están encerrados en su espacio limitado y mecanizados al realizar las tareas monótonas

1 Foster, 1977, 26.

2 Castagnino, 1970, 89. 
de siempre. No tienen derecho a cometer ni un solo error ${ }^{3}$ ya que se les considera como medio-autómatas. Tampoco se les permite mirar hacia fuera, al puerto, y sus movimientos son sincronizados y limitados a los estrictamente necesarios para llevar a cabo sus tareas. De pronto entra el ordenan$\mathrm{za}$, un mulato que sostiene haber corrido mundo como marino y empieza a invitarles a un escapismo imaginario hacia islas paradisíacas, mundos exóticos y vidas aventureras que hacen aún más fuerte el contraste entre su actual situación burguesa y la verdadera vida que se encuentra al otro lado de la ventana. Los burócratas se desconciertan, se dejan llevar por las descripciones del mulato y participan con él en un festín musical y de baile que exorciza su penosa vida cotidiana, hasta el momento en que entra de nuevo el Jefe interrumpiendo el sueño y devolviéndoles a la dura realidad. La resolución del Director supremo es cruel: despide a todo el personal y ordena poner vidrios opacos en la ventana. Las palabras de Castagnino son muy acertadas al respecto: «No soñar, no pensar; no sentirse individuo, sino cosa: el mundo moderno, en fin». ${ }^{4}$

Como se ha señalado, las deudas de esta pequeña pieza de Arlt para con la literatura universal son escasas e indirectas. La más explícita es la del símil de la caverna de Platón, que constituye uno de los ejes alrededor de los cuales se desarrolla el tema de la obra. Por lo demás, Arlt hace referencias implícitas a la literatura escapista clásica, al cuento del Flautista de Hamelín de los hermanos Grimm y a la pintura impresionista y cloisonista de Gauguin, sobre todo su etapa haitiana mediante el proceder, las palabras y las imágenes que dibuja con ellas el personaje del mulato.

\section{En la caverna de Platón}

Bien conocida es la parábola de la caverna que Platón expone en el libro VII de La República para referirse alegóricamente a la actitud del hombre respecto a la verdad y cómo termina siendo cautivo de sus temores e ignorancia frente a la vida. Epigramáticamente, basta con resumir aquí

3 «EL JEFE. - Otra equivocación, Manuel. MANUEL. - ¿Señor? EL JEFE. - Ha vuelto a equivocarse, Manuel. - Lo siento, señor. EL JEFE. - Yo también. (Alcanzándole la planilla). Corríjala. (Un minuto de silencio). EL JEFE. - María. MARÍA. - ¿Señor? EL JEFE. - Ha vuelto a equivocarse, María. MARÍA (acercándose al escritorio del JEFE). - Lo siento señor. EL JEFE. - También yo lo voy a sentir cuando tenga que hacerlos echar. Corrija»; Acto Único, 1991, 393.

4 Castagnino, 1970, 88-89. 
que Sócrates cuenta a su interlocutor Glaucón cómo unos hombres están prisioneros de nacimiento en una gruta cavernosa. Encadenados de manera que no pueden ver nada más que las sombras que proyecta una hoguera en la pared que se encuentra enfrente de ellos, pasan su vida viendo circular las proyecciones de animales y hombres, que de vez en cuanto paran y conversan entre sí. Las escenas que los cautivos ven en la pared se parecen al teatro de sombras chino y constituyen para ellos la única y absoluta verdad. Este es el mundo sensible en la filosofía del Platón. Lejos de donde ellos se encuentran encadenados está la salida de la cueva que da al mundo y a la naturaleza iluminada por el sol, y representa el mundo de las ideas platónico.

Sócrates le cuenta a Glaucón cómo finalmente uno de esos prisioneros logra librarse de sus cadenas y consigue salir afuera donde, después de haberle costado mucho adaptarse a las nuevas condiciones, se pone en contacto con el mundo que le estaba hasta aquel momento vedado. Detrás de la figura de este fugitivo se descifra la alegoría del filósofo, del hombre iluminado que ahora vuelve de nuevo a la cueva para liberar a sus antiguos compañeros esclavizados y hacerles partícipes de la gran verdad que acaba de descubrir, esto es, el mundo de las ideas, a la vez que desea revelarles que viven en un gran engaño. Sin embargo, lo triste de la condición humana, encadenada por la ignorancia y el temor hacia lo desconocido, hace que los prisioneros se burlen de su «apóstol» y, como afirma Sócrates, si tuviesen la oportunidad incluso lo hubieran matado. ${ }^{5}$

Se trata de una de las más bellas alegorías que nos ha dejado la literatura clásica, donde se pone de manifiesto cómo los humanos podemos engañarnos a nosotros mismos o ser oprimidos por convenciones ficticias e irreales.

\section{En la escena de Arlt}

Roberto Arlt retoma el símil platónico en La isla desierta donde nos presenta unos oficinistas esclavizados y robotizados que, por lo menos han ascendido desde los sótanos de la empresa donde trabajaban y donde no

5 Dicha fábula ha dejado su sello en la literatura universal como, a modo de ejemplo, en La vida es un sueño de Calderón de la Barca (1636), Un mundo feliz de Aldous Huxley (1932) o, en una manera aún más pesimista y opaca, en 1984 de George Orwell (1949). 
había luz del sol sino de bujías eléctricas, al décimo piso de la misma, donde tienen la posibilidad de observar a través de la ventana un mundo que les está prohibido. ${ }^{6}$ Sólo pueden mirar enfrente, pero aun así perciben los movimientos de la vida allí fuera, representada por los buques que entran y salen de la zona portuaria. La ventana juega el papel de actante en la pieza, puesto que desencadena la ruptura con la realidad siendo la fisura a través de la cual la fantasía irrumpe en la escena de la cotidianidad. Incluso al final de la obra, donde volvemos a la realidad cruel, el Director, después de despedir a todo el personal, manda poner vidrios opacos en las ventanas con tal de ocultar detrás de un velo la otra realidad, inquietante para los burgueses, sellando así la grieta.

El papel del filósofo-redentor lo desempeña el mulato Ordenanza, que ya se había escapado de este mundo infernal y ahora vuelve para salvar a los demás. A pesar de que al principio se topa con la incredulidad de los burócratas, al final consigue arrastrarlos a su mundo de las «ideas». Sin embargo, la crueldad de la vida cotidiana tiene su manera particular de asesinar los sueños de los hombres. Entra el Director supremo, junto con el Jefe del departamento, ejercen su poder despótico sobre ellos volviendo a encadenarlos (pese a haberles despedido, que es prácticamente lo mismo puesto que se les niega la posibilidad de soñar); y ordena reemplazar las ventanas por donde entraba la luz del sol con otras oscuras, devolviendo la oficina a su condición inicial de caverna platónica. ${ }^{7}$

6 En este sentido y como afirma Camacho: «[a]scender al décimo piso del bloque de oficinas no es sólo una forma de subir físicamente, sino sobre todo espiritualmente»; Camacho, 2001, 683.

7 Semejante parece haber sido la aproximación a la obra que realizó el Grupo Ojcuro del Teatro Ciego de Buenos Aires bajo la dirección de José Menchaca el 25 de octubre de 2001 en el Teatro Anfitrión. Condicionada la representación por cuestiones pragmáticas —el elenco se componía en gran parte por actores no videntes-y propuestas revolucionarias — sala totalmente oscura, los espectadores se guiaban por los actores, algo que recuerda la iniciación mística en un acontecimiento ceremonioso como debería ser el teatro-, consideramos que alcanzó el concepto platónico del mundo de las ideas en la sala teatral, pese a no haber sido este el propósito inicial del director. Remitimos a la descripción de la representación que se puede consultar en la página web: http://teatrociego. tripod.com/critical.htm (consultada: 10 de agosto de 2012). Asimismo, en el artículo de Gliona «La isla desierta. La cuestión escópica como experiencia perceptiva», se describe la representación realizada por el Grupo Ojcuro como acto de comunicación y de comunión entre los partícipes en ella, y el empleo para este fin de la gama de los signos semióticos que permiten establecer el diálogo entre el público (receptor) y el elenco (emisor) a base de recursos no visuales; Gliona, 2011, 347-349. Es asî como se consigue la captación de las «ideas» (en este caso, texto dramático) gracias al resto de los sentidos activados (tacto, olfato, oído) de los espectadores (sensu lato ya que ellos no pueden ver). De este modo, estos últimos construyen de manera simbólica y en su mente el universo ficticio que propone el discurso dramático arltiano, a la manera de un «texto partitura» — como lo llamó Bratosevich-que invita a la virtualización de la obra de manera subjetiva, como también del «cronotopo» —en palabras 
En cuanto al análisis estructural de la obra se puede afirmar que se trata de una pieza con escaso, si no nulo, desarrollo dramático, algo que invita a considerarla como metafórica y simbólica, despojada de las pretensiones milenarias de la acción teatral naturalista o realista. Siendo así, requiere del espectador una mirada oblicua respecto a su experiencia convencional que lo capacite para descifrar los significados del signo global que constituye la obra.

El ambiente que construye Arlt se basa en la antítesis entre la opaca realidad de los oficinistas y la luminosa verdad que se esconde detrás de las ventanas $^{8}$ y las descripciones y figura del mulato. En este sentido, el acontecimiento teatral en el que La isla desierta invita a participar y comulgar supone una enseñanza mística, en el sentido de los misterios de Eleusis, donde la ceremonia teatral misma o bajo la guía de los actores-hierofantes, pretende llevar al espectador de la oscuridad a la luz, tanto en términos platónicos como en términos de la praxis teatral que al otro lado del Atlántico ya se conocía como teoría de la crueldad. Sobre todo Cipriano representa la fuerza propulsora - el élan vital de Henri Bergson o la «fuerza vital» de Posidonio de Apamea- que empuja hacia la liberación de las fuerzas vitales que rigen el universo y que el modus vivendi contemporáneo intenta sofocar. Pues Cipriano desencadena la denodada búsqueda de la felicidad - que es una constante en la temática arltiana-, dando por sentado que si no existe felicidad tampoco existe vida. Invirtiendo el axioma, podríamos afirmar que para los personajes arltianos la vida sin felicidad es un gran fraude de Dios al hombre y del hombre mismo a la vida. Como señaló Mirta Arlt para la dramaturgia de su padre: «"Dios es la alegría de vivir" y todo lo que atente contra la alegría de vivir es enfermedad, peste, impureza que ataca a los humanos». ${ }^{9}$ Vemos que aparte del vitalismo bergsoniano que comparte Arlt con Artaud, también su hija Mirta asocia, quizás incons-

\footnotetext{
de Bajtín— en el cual el argumento se desarrolla; Bratosevich, 1985, 262. Así, la representación propuesta se convierte en un espectáculo de subjetividades, condicionada por la «transducción» —siguiendo la nomenclatura introducida por Bobes Naves - que realiza cada invitado en este acondecimiento teatral; Bobes Naves, 1997, 20. Cabe añadir que dicha propuesta del Grupo Ojcuro reivindicó la importancia todavía innovadora de esta obra de Arlt puesto que fue elegida sesenta y un años después de su primer estreno para representar a la Ciudad de Buenos Aires en el Encuentro Internacional de Teatro Experimental que se realizó en Rosario, Argentina en 2002.

8 Arlt marca esta antítesis desde el principio: «Son las dos de la tarde, y una extrema luminosidad pesa sobre estos desdichados simultáneamente encorvados y recortados en el espacio por la desolada simetría de este salón de un décimo piso»; Acto Único, 1991, 393.

9 Arlt, Mirta: «Presentación», en Arlt, Roberto: Teatro completo, Buenos Aires, Editorial Schapire, 1968, 12; citado por Foster, 1977, 34 (la cursiva es nuestra).
} 
cientemente, el proyecto de su padre para el teatro convencional con la metáfora de la peste y la enfermedad, algo que hacía al mismo tiempo Artaud en su manifiesto de la crueldad.

\section{Desterrando la peste del teatro: la poética de Antonin Artaud}

Venganza por venganza, y crimen por crimen es el grito de Artaud frente el arte depravado burgués. ${ }^{10}$ Destrucción total, sin "perder tiempo rompiendo lanzas contra las concepciones frívolas o degradadas del teatro europeo». ${ }^{11}$ Verdadero apasionado del ideario surrealista el francés visionó un teatro consciente de su imposibilidad, como una profecía escatológica de la muerte violenta del teatro convencional burgués, y trascendental para el retorno del arte a sus orígenes.

Artaud pregonó un teatro que constituyera una necesidad de comunicación a través de la participación activa de los partícipes en el espectáculo teatral. Es por ello que en el ideario artaudiano la escena se convertiría en el espacio mágico donde un nuevo hombre nacería, puesto que el género teatral no debía estar destinado para ofrecer diversión ni evasión, sino liberación de una fuerza agitadora. La escena debía recobrar su funcionalidad ancestral y ontológica como despertadora de conciencias y ejercer el papel curativo del arte, re-creando el hombre. Aspiró a constituir un teatro que fuese el doble invertido y revertido de la vida, pero no menos real que ella. Hay que señalar también al respecto la atracción que sentía Artaud por las ciencias ocultas, con las referencias constantes a rituales y fórmulas mágicas, y la conexión que deseó establecer entre teatro y alquimia. De ahí surgieron textos fundamentales para su poética como El teatro alquímico (1932) o El teatro y su doble (1938).

Artaud propuso no sólo devolver el teatro a sus orígenes, sino, también, al modo de las representaciones místicas y primitivas. Pregonó la liberación de las fuerzas de la vida identificándose con ella en un modo nietzscheiano de arte dionisíaco y la desligación del acto escénico de la primacía del texto dramático. La innovación de Artaud en ese aspecto es que, al contrario de los intentos anteriores para la eliminación de la escena, éste trabaja para la desligación de ella del texto, convirtiendo al acontecimien-

10 Artaud, IV, 1956, 35.

11 Abirached, 1994, 321. 
to teatral en el triunfo de la puesta en escena pura. El director y los participantes (espectadores y actores) dejarían de ser instrumentos de la representación. Los actores no deberían tener miedo de la sensación, de identificarse con el dolor y la alegría y vivir plenamente lo que se les otorga para interpretar creyendo en lo que hacen.

No obstante, el empeño profano de la poética de la crueldad no refuta el valor hierático del teatro. El proyecto de Artaud fracasa si el espectáculo no se convierte en experiencia mística, reveladora de la fuerza de la vida en su primer despertar. En este sentido, es una experiencia religiosa. El autor es reemplazado por el director de la escena, el nuevo «hierofante» o houngan —según la definición que prefiere Peter Brook refiriéndose a la ritualidad de la crueldad $-{ }^{12}$ en las ceremonias teatrales. El objetivo principal de la escena de la crueldad es el despertar de las funciones primitivas de la naturaleza, escondidas en el inconsciente. Se trata de un exorcismo o expiación que intenta hacer fluir nuestros demonios.

Los actores se convierten entonces en los verdaderos agentes de esta comunicación religiosa. El personaje debe identificarse con su máscara, prescindiendo de todo lo que no es esencial y limitándose a unos pocos rasgos esenciales. La representación se vuelve en este sentido en una suerte de evocación, de rito peligroso con el cual el actor, despojándose de la propia realidad individual trata de atraer hacia sí, frente al público, un ser que proviene de un mundo superior, el del arte. El actor se vuelve oficiante de un ritual poseído por el personaje, al que evoca interpretándolo; siempre guiado por el texto que ya es un libro de fórmulas mágicas en el ritual que tiene lugar en el «templo» que es la escena, y que reúne a los «creyentes» espectadores. En esta revisión de la dramaturgia se rescata lo material de la escenificación teatral como medio indispensable para la evocación del personaje y la posesión del actor por él. Así, el teatro vuelve a su origen como rito y ceremonia esotérica para unos pocos iniciados, capaces de comprender y participar en esa experiencia.

En la poética de la crueldad no se postula una teatralidad de terror y sangre, ni necesariamente de violencia física cuando Artaud habla de «venganza y crimen», sino que más bien, su teatralidad remite ante todo a una crueldad ontológica, vinculada al sufrimiento de existir y a la miseria del cuerpo humano. En este sentido, la crueldad que propone Artaud constituye una metáfora de la verdadera esencia de la vida y del destino humano.

12 Brook, 1997, 82. 
Pues cada teatro que anhela resultar digno de este nombre, debe aportar al espectador la conciencia cruel de la crueldad de la vida ${ }^{13}$ y llevarle al estado de esta recuperada catarsis que el marsellés desea para el arte dramático. Por eso metaforiza equiparando la peste con la situación del teatro occidental. ${ }^{14}$

En cuanto a la representación misma, en el teatro de la crueldad el espectador se encuentra en el medio del espectáculo que lo rodea. «La distancia de la mirada ya no es pura, no puede abstraerse de la totalidad del medio sensible; el espectador invadido ya no puede constituir su espectáculo; hay una fiesta». ${ }^{15}$ El mérito de un (p)acto parecido es su imposibilidad repetitiva. Y este es el proyecto metafísico de Artaud: la eliminación de la repetición que es enemigo de la vida en su flujo continuo, puesto que cualquier acto de repetición aniquila la vida.

\section{El personaje y su ontología en la escena de la crueldad}

Artaud no propuso una compacta y coherente teoría respecto al tratamiento del personaje, sino que procediendo por pura intuición, se rastrea que sus ideas en cuanto al tema se dedujeron —manteniéndose siempre fieles al principio taumatúrgico-terapéutico y, en todo caso, sagrado de la interpretación- de la negación de los principios aristotélicos de la mimesis, una vez rechazada la fábula, y de su propia experiencia de actor con los ejercicios corpóreos-respiratorios e improvisaciones que él mismo efectuaba. En cuanto al carácter sagrado del actor, éste debe vaciarse convirtiéndose en el vehículo humano de las fuerzas vitales que rigen la escena una vez evocadas, con tal de que vuelva a ponerse en comunicación directa con los fieles, es decir, el público.

Abirached esbozó las características de los personajes del teatro de la crueldad de la siguiente manera: ellos no tienen un estado civil concreto; no obedecen a las leyes de la gravedad, ni sucumben a la servidumbre de

13 Brunel, 1982, 17.

14 Señala Dubatti al respecto: «El teatro y la peste son fuerzas disolutorias, de rebelión y destrucción, contra la negatividad de las convenciones en las que se ha asentado la cultura de Occidente», y operan como «una vuelta a las raíces del hombre y la vida». En este sentido, el cuerpo del actor constituye el lugar de generación de la «apocatástasis» y, por consiguiente, de la catársis anhelada: «El lugar de acontecimiento del teatro es el cuerpo del actor hierofánico»; Dubatti, 2008, 78-79, 82.

15 Derrida, 1968, 75. 
la duración, las coordenadas del espacio, los principios racionales de identidad, causalidad y no contradicción. Tampoco se comportan según las exigencias de una fábula inteligible por medio de la razón, sino que lo que hacen o dicen, les está dictado desde fuera. No tienen un origen concreto; al contrario, su entidad emana del inconsciente colectivo y de las leyendas de lugares remotos e imprecisos. Casi siempre se acompañan por un doble y a menudo se sumergen en la muchedumbre que les rodea hasta llegar a perder en ella su nombre identificador. ${ }^{16}$

Estos personajes están siempre rodeados y acompañados de todos los signos no-verbales que se pueden emplear sobre escena: sonidos, música, objetos insólitos, maniquíes, luces y colores, y se encuentran perennemente regidos por una gama de pulsiones homicidas y sexuales, obsesiones escatológicas y torturas de conciencia. Estas pulsiones les impiden cristalizarse en el cuerpo del actor, manifestarse coherentemente en la escena, condenados en los límites de la existencia y, de cualquier modo, en su provisionalidad. Es el actor quien les presta su propia sangre y les hace visibles en la escena. Sin él, simplemente no existen; abren los ojos en el primer despertar de la nueva vida del actor y los cierran cuando él de nuevo deja su último aliento al caer el telón, condenando su existencia al recuerdo de los jeroglíficos que testimoniaron su paso por este universo dramático.

\section{La poética de la crueldad y su utopía escénica}

Artaud no sólo marcó su sello en el arte dramático del siglo XX, sino que compuso sistemáticamente una nueva ars poetica, ${ }^{17}$ que postuló tirar al fuego los cánones aristotélicos y canonizar la naciente escena occidental del arte dramático contemporáneo. Sin embargo, es interesante que este rechazo de la poética aristotélica se hubiese basado en unos de los principios más elementales de la misma, es decir, la piedad y el temor como medios para la purificación de las pasiones, según Aristóteles, o la crueldad y el terror, según Artaud. No obstante, sus acciones no producen el

16 Abirached, 1997, 358.

17 En efecto, Brunel señala lo mismo cuando escribe: «on a parlé, à ce propos, de révolution théâtrale et l'on peut en effet avoir l'impression que ce nouvel art poétique effaçait les données de la Poétique d'Aristote [...]»; Brunel, 1982, 10. Sin embargo, en las conclusiones de su estudio, Brunel reconcilia la poética artaudiana con los principios aristotélicos, basándose más bien en los efectos psíquicos y emocionales que fundamentan la poética de Aristóteles y ya no en el axioma que le constituye como el filósofo de la razón; Ibidem, 151-155. 
«temor» aristotélico sino el horror por lo monstruoso que, como explica Brereton, no cabe dentro de la concepción catártica. ${ }^{18}$

En el nuevo concepto del arte dramático que evoca la vanguardia y pregona Artaud desde Francia, como Arlt desde Argentina, lo monstruoso forma parte de la nueva estética — como forma parte de la naturaleza humana- y el teatro debe aclamarlo y reclamarlo como algo suyo, puesto que la tragedia es, desde el punto de vista schopenhaueriano, el arte que mejor refleja la naturaleza humana. Por ello el teatro se basa en el espectáculo como totalidad $\mathrm{y}$, en este conjunto, la escenografía juega un papel fundamental provocando horror por lo monstruoso y la crueldad de las acciones de sus personajes mediante efectos escénicos.

No obstante, el teatro de Artaud residió en su propia consciente imposibilidad, igual de utópico que todos los proyectos vanguardistas. Los límites de la escenificación, de las formas verbales y gestuales del teatro tradicional, la misma anulación de la repetición se asientan en la paradoja de la repetición del parricidio, ${ }^{19}$ en la conciencia de la imposibilidad del teatro que desea anular la escena buscando producirla. Un teatro de repetición de lo que no se repite, la repetición de la diferencia. Tal es el límite de una crueldad que comienza por su propia representación. El teatro más fiel a las vanguardias históricas, puesto que anuncia su propia muerte como manifestación.

\section{La ensoñación cruel de los personajes arltianos}

En La isla desierta, como en casi todo el teatro arltiano, la verdadera representación se enfoca en la proyección de los sueños o pesadillas desen-

18 Brereton analizó las diferencias entre temor, terror y horror, concluyendo que el horror presupone lo repugnante y lo mórbido, y, por ende, se excluye de la tragedia por ser una emoción de baja categoría; Breretón, 1968, 38. Lo mismo había comentado Aristóteles señalando que para provocar el efecto del horror por medio del espectáculo y no de la imitación ni la trama, es preciso recurrir a la ayuda escenográfica, algo que califica la obra dramática en cada caso como menos merecedora de evaluarse stricto sensu como trágica.

19 Nos referimos al concepto del parricidio artístico que parte de la crítica psicoanalítica, y que deriva del concepto de Lacan del deseo como una carencia. Cada deseo emana de una carencia que el sujeto lucha por satisfacer. Allí radica también la aplicación que Harold Bloom hizo del concepto freudiano del «complejo de Edipo» en la literatura, en su libro The anxiety of influence. A theory of poetry. Los autores luchan por escaparse de la sombra de sus antecesores-«padres» literarios. Intentando «castrarlos», «penetran» en sus textos y escriben en un modo que revisa, expulsa y remodela las formas literarias de los autores anteriores. Se trata de una especie de parricidio con la pluma. Terry Eagleton, en su Literary theory: an introduction, expone el concepto de Bloom y su aplicación en la literatura. Citamos de la traducción de su libro en griego, 1989, 243-273. 
frenadas de los personajes. Los burócratas proyectan sus dobles en la negación absoluta de la cultura occidental. Se encuentran libres de todas las convenciones que homogeneizan a los miembros de las sociedades, ${ }^{20} \mathrm{se}$ rebelan y se igualan a la vida, al doble de la vida que, sin embargo, no se puede considerar menos posible o tangible que la vida real. De modo que Arlt realiza en esta pieza la alquimia teatral del teatro de la crueldad, materializando la atormentada vida interior de un grupo pequeño de hombres que se sienten defraudados por la sociedad de la que forman parte. La afirmación de la vida deseada se deja desdoblar y vaciar por la negación del modus vivendi que les atormenta. Por eso, niegan la realidad cotidiana frente a la otra soñada. No obstante, al final de la pieza, lo cotidiano triunfa y vuelve a afirmarse, no por su verdad absoluta, sino por su autoridad. Los burócratas de la obra de Arlt rechazan la muerte de sus sueños, pero terminan afirmándola como acto sin retorno. En este sentido, desde el punto de vista dialéctico, afirmar rechazando es lo mismo que rechazar afirmando.

No obstante, esta transición semántica de una realidad frágil que se balancea a otra anárquica que libera se realiza esquemáticamente en la pieza en sólo un acto de una escena, que, empero, podría fragmentarse en cuatro: a) la pequeña escena que abre la obra donde se nos presenta la severa y ordenada realidad de los oficinistas, que, sin embargo, deja percibir por debajo la rebelión latente; b) el primer acto de rebeldía que estalla en la persona de Manuel; c) la salida del Jefe que representa la tiranía de la realidad y la entrada de Cipriano que personifica la posibilidad utópica de otra vida risueña; por último, d) la entrada de nuevo del Jefe junto al Director quienes reestablecen mediante su crueldad el despotismo de la cotidianidad. En este sentido, la estructura dramática funciona a partir del esquema triangular Realidad-Fantasía-Realidad.

En todo este proceso Arlt usa signos sonoros y visuales para marcar la ruptura gradual de los distintos planos en los que se edifica la obra. Los signos verbales parecen consecuencia de los anteriores que son más sensoriales. Así, por ejemplo, en la primera ruptura que acabamos de describir leemos en el texto de Arlt:

20 La cuestión de la homegeneidad en la sociedad como aversión a la diversidad individual y de la alteridad en las artes —y más específicamente en el arte escénico- como otro más elemento sígnico y factor perturbador que evoca en la mente de los espectadores la inevitable transitoriedad de nuestra existencia como seres humanos, ha sido tratada en el interesante artículo de Nara Salles y Felipe M. Oliveira $(2012,74-86)$. 
Nuevamente hay otro minuto de silencio. Durante este intervalo pasan chimeneas de buques y se oyen las pitadas de un remolcador y el bronco pito de un buque. Automáticamente todos los EMPLEADOS enderezan las espaldas y se quedan mirando la ventana [...]. EMPLEADO $1 .^{\circ}$ (con un apagado grito de angustia). - ¡Oh! No; no es posible. (Todos se vuelven hacia él.) [...]. MANUEL. - No es posible trabajar aquí (...). Los culpables que nos equivoquemos son esos malditos buques [...]. Los buques que entran y salen, chillándonos en las orejas, metiéndosenos por los ojos, pasándonos las chimeneas por las narices $[\ldots]{ }^{21}$

Además, es notable que a menudo Arlt no utilice dichos signos como captados de inmediato por el espectador, sino que opte por transmitirlos a través de las descripciones de los actores, como si fueran los agentes mediante los cuales se canaliza la energía que va a hacer estallar la presencia de la energía agitadora en la escena, a la manera de la poética de la crueldad artaudiana. En este sentido, el sistema semiótico que Arlt emplea sirve para transmitir la euforia progresiva de los personajes que pasan de la rutina nociva a la revuelta impulsiva y, de ahí, al éxtasis de sus sueños escapistas que por momentos se materializan, arrastrando a los espectadores en este frenesí ritual y sus sueños de libertad.

En ese sistema sígnico Arlt añade la figura de Cipriano quien, con su piel de mulato — entre el puritanismo y la urbanidad que representa el hombre blanco y la libertad y sensacionalismo afinado a la tierra que representa el hombre de color - y sus tatuajes (verdaderos jeroglíficos que evocan otras tierras e invitan al escapismo), ${ }^{22}$ juega el papel del redentor-hierofante que canaliza la energía latente y evoca la materialización de los sueños exóticos de los burócratas mediante el baile y el ritmo frenético de los tambores. A través de Cipriano las imágenes que él fabrica se materializan y los covachuelistas se transforman en aventureros que se quitan sus «uniformes» pequeño-burgueses; junto con ellos también lo hacen los espectadores. Se trata, como lo define David Viñas, de un «strip-tease» que invita a abandonar los atavíos de la cultura victoriana. ${ }^{23}$ Un acto cruel, metáfora de la ruptura total, que impele a volverse salvaje y renegar de la civilización burguesa. En este sentido el baile se transforma en una fiesta de bajos instintos, no necesariamente violento pero sí cruel en la contraposición con la realidad convencional de los partícipes. No obstante, la crueldad da un paso

21 Acto Único, 1991, 393-394.

22 Véase al respecto el interesante estudio que realizó en su ya citado artículo Camacho con respecto a la funcionalidad simbólica de los tatuajes de Cipriano; Camacho, 2001, 686-690.

23 Fragmento de una conferencia pronunciada por David Viñas en «Las jornadas preparatorias para la creación de la Universidad Popular Madres de Plaza de Mayo», recopilado en la página web http://sololiteratura.com/arlt/arltteatro.htm (consultada: 10 de marzo de 2011). 
más con la interrupción repentina del éxtasis colectivo por la irrupción del Jefe y del Director que despiden a todos, devolviendo también a los espectadores al orden preestablecido del antropófago monstruo urbano que constituyen las exigencias de la vida moderna y que exige el sacrificio de los sueños de los hombres en su altar sangriento.

\section{El teatro sagrado}

Puntualizando las exigencias del teatro de la crueldad ya hemos visto que en esta pieza se pueden ubicar puntos de contacto entre los proyectos de Artaud y Arlt, respectivamente. En este sentido, no podemos dejar pasar la constancia programática en Artaud, y temática en Arlt, de reemplazar al hombre en su lugar poético dentro de lo que convencionalmente llamamos realidad. Los burócratas optan por la rebelión y la anarquía inspiradas por Cipriano, quien juega el papel del dirigente frente a la autoridad del Jefe y del Director. El medio para la rebelión es la fantasía, este soñar despierto típico de Arlt, que libera y desplaza de la crueldad de la realidad cotidiana y objetiva a la alternativa de otra subjetiva. Merece la pena señalar que esta pequeña pieza de Arlt es la única donde el sueño cobra valor colectivo en lugar de tratarse de una ensoñación individual como sucede en el caso de Trescientos millones (1932) o El fabricante de fantasmas (1936). Empero, el resultado es el mismo. ${ }^{24}$ Los personajes se convierten en los dobles de sí mismos proyectándose en la pantalla del deseo de una isla paradisíaca, donde comparten colectivamente las imágenes exóticas y poéticas con las que alimenta sus fantasías el hierofante Cipriano. ${ }^{25}$

24 La gradual sumersión en el estado de ensoñación de la Sirvienta desilusionada por sus sueños frustrados en Trescientos millones, por una parte, y el fantaseo metaliterario del burgués Pedro que lucha contra los demonios que él mismo había evocado y que lo hostigan hasta el suicidio como erinias por el asesinato de su esposa, por otra, se equiparan en la dramaturgia arltiana a los sueños frustrados de libertad de los covachuelistas de La isla desierta, aunque la «muerte» de estos últimos tiene su referencia metafórica al asesinato de sus sueños escapistas. La diferencia entre las piezas en cuestión es que en las dos primeras la muerte viene de la propia mano de los protagonistas, mientras que en La isla desierta se trata del asesinato metafórico de la libertad individual por la imposición de la autoridad de parte del Director. En cualquier caso, la producción arltiana nos ofrece una mirada sobre el mundo de la fantasía, la ilusión y la desilusión totalmente hostigado por convenciones que a su vez constituyen una realidad que coexiste con el primer plano de la vida de los caracteres y «sella» el modus operandi temático de Arlt y de sus personajes como somniare ergo sum, algo que consolida la temática de la duermevela como característica de buena parte de su dramaturgia.

25 «MULATO. - [...]. Todos viven desnudos entre las flores, con collares de rosas colgantes del cuello y los tobillos adornados de flores. Y se alimentan de ensaladas de magnolias y sopas de violetas», Acto Único, 1991, 399. 
Sus palabras parecen las recitaciones que evocan otra realidad para lograr que se materialice sobre la escena y llevar progresivamente al clímax del festín a los participantes. En esta ceremonia hacen falta los jeroglíficos que evocan imágenes del inconsciente colectivo (los tatuajes del mulato Cipriano) y los indígenas que describe y cuya imagen se materializa mediante su «logos». Efectivamente, en esta última oración-recitación del mulato todos los personajes responden al unísono como si se tratara de las respuestas ritualizadas en una ceremonia sagrada que Arlt quisiera insinuar recalcando el carácter sacro del teatro. ${ }^{26}$ Ya no valen sólo las palabras, sino que hay que recurrir a gestualidades, signos cinéticos-proxémicos y de vestuario improvisado para intensificar la climatización de lo ritualizado en este momento de la obra: «MULATO (fabricándose una corona con papel y poniéndosela). - Los brujos llevan una corona así y nadie los mortifica». ${ }^{27}$ El carácter sagrado de la ceremonia teatral se hace ya cada vez más explícito y para resaltarlo aún más, Arlt matiza el discurso del sacerdote mulato con nomenclatura religiosa. Así, empieza su siguiente oración con la afirmación propia de la retórica apocalíptica de los apóstoles con un «Y digo que es muy saludable vivir así libremente ${ }^{28}$ que comparamos con las palabras bíblicas de Jesús: «Y os digo que todo aquel que me confiese delante de los hombres $[\ldots] \gg .^{29}$ Añade además el salvajismo y el hedonismo bacanal, propio del tipo de rituales a los que Cipriano ${ }^{30}$ les invita a participar: «MULATO. - [...]. Cuelgan libremente de las ramas y quien quiere, come, y quien no quiere, no come... y por la noche, entre los grandes árboles, se

26 «MULATO. - Siempre bajo los árboles hay hombres y mujeres haciéndose tatuar. Y uno termina por no saber si es un hombre, un tigre, una nube o un dragón. TODOS. - ¡Oh, quién lo iba a decir! ¡Si parece mentira!»; Acto Único, 1991, 398.

27 Idem.

28 Ibidem, 399.

29 Lucas, 12:44. El carácter didáctico-apocalíptico del papel de mulato es evidente en este momento del desarrollo de la trama, imponiéndose cada vez más como sacerdote, apóstol y redentor, cuya autoridad promete castigos si no se arrepienten y participan en la comunión los fieles extraviados: «Ved cuán noble es su corazón. Ved cuán responsables son sus palabras. Ved cuán inocentes son sus intenciones. Ruborizaos amanuenses. Llorad lágrimas de tinta. Todos vosotros os pudriréis como asquerosas ratas entre estos malditos libros. Un día os encontraréis con el sacerdote que vendrá a suministraros la extremaunción. Y mientras os unte con aceite la planta de los pies, os diréis: “¿Qué he hecho de mi vida? Consagrarla a la teneduría de libros". Bestias. [...]. Aprovechen ahora que son jóvenes. Piensen que cuando les estén untando con aceite la planta de los pies no podrán hacerlo»; Acto Único, 1991, 400.

30 Merece la pena señalar que, desde el punto de vista del análisis que realizamos, no parece casualidad que Arlt hubiera elegido el nombre de Cipriano para su personaje, con la asociación explícita que se puede hacer con la persona controvertida de San Cipriano, el arrepentido mago que se convirtió al cristianismo y a quien se considera el protector de los magos. 
encienden fogatas y ocurre lo que es natural entre hombres y mujeres». ${ }^{31}$ Para culminar el proceso ritual de la ceremonia teatral sólo falta añadir la música y el baile, y eso es lo que sucede cuando el houngan-Cipriano ${ }^{32}$ coge la tapa de una máquina de escribir y la transforma en tambor:

El mulato toma la tapa de la máquina de escribir y comienza a batir el tam tam ancestral, al mismo tiempo que oscila simiesco sobre sí mismo. Sugestionados por el ritmo, van entrando todos en la danza. MULATO (a tiempo que bate el tambor). - Y también hay hermosas mujeres desnudas. Desnudas de los pies a la cabeza [...]. $\mathrm{Y}$ hermosos hombres desnudos. Que bailan bajo los árboles, como ahora nosotros bailamos aquí... [...]. La danza se ha ido generalizando a medida que habla el MULATO, y los viejos, los empleados y las empleadas giran en torno de la mesa, donde como un demonio gesticula, toca el tambor y habla el condenado negro. Y bailan, bailan, bajo los árboles cargados de frutas. De aromas... Histéricamente todos los hombres se van quitando los sacos, los chalecos, las corbatas; las muchachas se recogen las faldas y arrojan los zapatos. El MULATO bate frenéticamente la tapa de la máquina de escribir. $Y$ cantan un ritmo de rumba... ${ }^{33}$

No obstante, a menudo las fuerzas que acuden no son las originalmente evocadas, como sucede con los espíritus en este tipo de ceremonias. Así, la obra y el festín pagano terminan con la irrupción del Jefe y del Director que como fuerzas del mal imponen las reglas de autoridad y austeridad de la moderna sociedad urbana. Sin embargo, lo que es importante es la energía que queda después del ritual teatral, igual que en las exigencias de Artaud para el teatro sagrado. Se trata pues de una vuelta al proto-teatro primitivo y la comunión tribal.

Con este último, el acto teatral se vuelve un verdadero acontecimiento comunicativo mediante una amplia aproximación semiótica al espectáculo propuesto por Arlt en las didascalias, donde ya no sirve sólo el texto dramático sino, también, el texto espectacular, y donde los gestos, las luces, la música y el ritual se articulan y se relacionan entre sí de manera coherente, como verdaderos criptogramas que testimonian su paso por la escena teatral, hasta que el signo global que es la obra adquiera el carácter comunicativo que también Artaud postulaba.

Los personajes que Arlt nos presenta están divididos en tres categorías. Por una parte tenemos el conductismo colectivo de los oficinistas que,

31 Ibidem, 401.

32 Citamos en este punto la descripción del teatro de la crueldad ceremonioso que realizó Peter Brook asimilando la representación cruel con los rituales vudú; Brook, 1997, 82.

33 Acto Único, 1991, 401-402. 
salvo algunas excepciones, se comportan y hablan al unísono. El otro personaje catalítico es el del Cipriano, el mulato que juega el papel del redentor social, del líder que conduce a los demás a la rebelión. Por último, Arlt esboza los otros dos personajes, el Jefe y el Director, que representan la autoridad del convencionalismo y la cotidianidad sobre los sueños humanos. Por eso mismo, los empleados al principio se nos presentan matizados por una fuerte imagen expresionista, encorvados, robotizados y víctimas del hipertecnicismo de la era moderna. Por otra parte, la misma elección impersonal del nombre del Jefe es indicativa del personaje que representa y se nos presenta como un militar que ejerce su autoridad sobre los reclutas, con una apariencia estereotipada. ${ }^{34}$ En cuanto al Director, no aparece sino en el último instante de la obra. A él pertenece la última palabra pero su presencia está latente durante toda la pieza, como espada de Damocles que representa la autoridad suprema que reestablece el imperio de la crueldad. Por ello, no hace falta dibujarlo sino que su sombra se nos figura como grisácea y opaca, algo que se verifica por su orden de poner vidrios oscuros en lugar de la gran ventana anterior.

Si comparamos las características de los personajes de la poética de la crueldad con los que nos presenta Arlt en La isla desierta, se puede comprobar que en ambos casos comparten rasgos comunes. Pues para Artaud los personajes de la crueldad no tienen origen ni en el tiempo ni en el espacio, sino que parecen halos sobre el universo teatral. Puede que los burócratas de la oficina portuaria sean al principio y a propósito los más «metropolizados» de su producción dramatúrgica para recalcar el contraste entre la vida ruin que soportan y la vida soñada que anhelan, pero, y como sucede en todo el teatro arltiano, rápidamente se elevan en la esfera de la fantasía y se nos presentan meteoros sobre la esfera teatral, fuera del espacio y del tiempo, hasta que la crueldad de la vida cotidiana los aterriza inopinadamente de nuevo hasta la miseria de su existencia burguesa. Todo lo que ellos hacen y dicen les está dictado desde fuera - al principio del Jefe, luego del mulato y, finalmente, del Director-, por una voluntad que procede a sobresaltos, choques, sorpresas y asociaciones insólitas. En el teatro de la crueldad, si los personajes tienen una identidad o un origen,

34 «En el centro y en el fondo del salón, la mesa del JEFE, emboscado tras unas gafas negras y con el pelo cortado como la pelambre de un cepillo»; Ibidem, 1991, 400. Merece la pena señalar que las gafas negras que gasta el Jefe contrastan con la perspectiva de la ventana luminosa por la que comienza la rebelión de los empleados, como si Arlt quisiera indicarnos que la autoridad no desea ver la verdad. 
hay que buscarlo en las leyendas de países lejanos o estereotipos conocidos en Europa: Cipriano es el buen salvaje, ora agitador ora redentor, que personifica el personaje arquetípico de la vida libre y despreocupada. Por otra parte, mantiene correspondencias con las leyendas medievales europeas, como es el caso ya señalado del mito alemán del Flautista de Hamelín. En cuanto al Jefe, ya hemos descrito que su figura estereotipada, con las gafas negras y el pelo cortado a cepillo remite a las figuras del militar y, en todo caso, a las figuras representativas de autoridad absoluta.

Por último, los personajes que describe Artaud se sumergen en la muchedumbre hasta perder su nombre identificador. En La isla desierta los covachuelistas, salvo Manuel y María — que por momentos emergen de la masa impersonal y compacta del personal de la oficina-, pierden su nombre identificador, se homogenizan y se caracterizan simplemente por sus cargos enumerados en la empresa (Empleado 1. ${ }^{\circ}$, Empleado 2. ${ }^{\circ}$, Empleada 1. ${ }^{\mathrm{a}}$, Empleada 2. ${ }^{\mathrm{a}}$, Empleada 3. ${ }^{\mathrm{a}}$, Tenedor de Libros).

Se puede objetivar que en el teatro de Arlt no se da, strictu sensu, la violencia física que caracteriza en parte la poética de Artaud. No obstante, la violencia puede ser una actitud subjetiva, aunque moralmente definida y objetivada por la sociedad burguesa y su manifestación artística. En este sentido esta praxis burguesa no deja de ser violenta en su origen, aplicación y fines, y no necesariamente tiene que ser explícitamente física, sino más bien moral y psicológica, como a menudo se da en la cosmovisión dramática arltiana. De modo que no se puede discrepar la violencia, a veces, también física, latente y constante, pero en cualquier caso imperante en el teatro de Roberto Arlt.

Sin perder de vista que no buscamos escritos de papel de carbón en el teatro de Roberto Arlt, ${ }^{35}$ sino correspondencias programáticas y afinidades temáticas entre la dramaturgia del argentino y la teoría de Artaud averiguamos analogías entre estos grandes revolucionarios en esta pieza apasionante de Roberto Arlt, que con razón Raúl Larra caracterizó como: «una pequeña obra maestra, de una intensidad inigualada, con ese toque inesperado, con ese impromptu que desvanece toda la imagen de un sueño». ${ }^{36}$ De todos modos, como señaló Peter Brook — uno de los discípulos de Artaud - respecto a la cuestión que aquí tratamos, «al igual que ocurre con

35 Algo que hubiera sido notoriamente anti-artaudiano teniendo en cuenta la repulsión del francés contra cualquier tipo de repetición o imitación.

36 Larra, 1950, 92. 
todos los profetas, debemos distinguir al hombre de sus seguidores». ${ }^{37}$ En este sentido, aquí hemos abogado por una evolución alternativa - darwiniamente hablando - basada en el gen original esparcido por Artaud y no en clones que siguieron los mismos patrones, algo que para el marsellés hubiera equivalido a la muerte ineludible. El nihilismo existencial de Roberto Arlt, fue enriquecido por la teoría activista y escénicamente revolucionaria de Antonin Artaud, teniendo como fondo la escena platónica por excelencia, constituyendo una original y bella ósmosis para una visión dramática tan trascendental.

Recibido el 30 de octubre de 2012

Aceptado el 6 de febrero de 2014

\section{Bibliografía}

Abirached, Robert: La crisis del personaje en el teatro moderno, Madrid, Publicaciones de la Asociación de Directores de Escena de España, 1994.

Arlt, Roberto: Obra Completa, III, Buenos Aires, Planeta, 1991.

Artaud, Antonin: CEuvres complètes, XXVI, Paris, Gallimard, 1956.

Bobes Naves, María del Carmen: Semiología de la obra dramática, Madrid, Arco Libros, 1997.

Bajtín, Mijaíl: Teoría y estética de la novela, Madrid, Taurus, 1991.

Berg, Walter Bruno: «Roberto Arlt. ¿Autor de un teatro de la crueldad?», en Morales Saravia, José y Schuchard, Barbara (eds.), Roberto Arlt. Una modernidad argentina, Madrid, Iberoamericana, 2001, 139-156.

Bratosevich, Nicolás: «Reflexiones semióticas sobre el Retablillo de Don Cristóbal», Filología, XX, 2, 1985, 261-278.

Brereton, Geoffrey: Principles of tragedy. A rational examination of the tragic concept in life and literature, London, Routledge \& K. Paul, 1968.

Brook, Peter: El espacio vacío. Arte y técnica del teatro, Barcelona, Península, 1997.

Brunel, Pierre: Théâtre et cruauté. Ou Dionysos profané, Paris, Librairie des méridiens, 1982.

Camacho Delgado, José Manuel: «Realidad, sueño y utopía en La isla desierta. Un acercamiento al mundo teatral de Roberto Arlt», Anuario de Estudios Americanos, LVIII-2, 2001, 679-690.

Castagnino, Raúl: El teatro de Roberto Arlt, Buenos Aires, Nova, 1970.

37 Brook, 1997, 68. 
Derrida, Jacques: «El teatro de la crueldad y el cierre de la representación», en Blanchot, Maurice y Roy, Claude (eds.), Artaud. Polémica, correspondencia y textos, Buenos Aires, Editorial Jorge Álvarez, 1968, 59-83.

Dubatti, Jorge: «Antonin Artaud, el actor hierofánico y el primer Teatro de la Crueldad», Revista Colombiana de las Artes Escénicas, 2.1, 2008, 70-83.

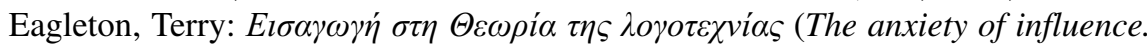

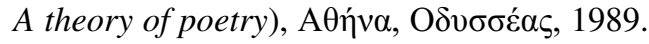

Foster, David William: «Roberto Arlt's La isla desierta. A structural analysis», Latin American Theatre Review, XI-1, 1977, 25-34.

Gliona, Lucía: «La isla desierta. La cuestión escópica como experiencia perceptiva», Telón de fondo, 13, julio 2011. Web: http://www.telondefondo.org/ numeros-anteriores/numero13/articulo/349/la-isla-desierta-la-cuestionescopica-como-experiencia-perceptiva.html (consultada: 29 de septiembre de 2013).

Graver, Daniel: «Antonin Artaud and the Authority of Text, Spectacle, and Performance» en Harding, James M. (ed.), Contours of the Theatrical AvantGarde. Performance and Textuality, Ann Arbor, University of Michigan Press, 2000, 43-57.

Larra, Raúl: Roberto Arlt El torturado, Buenos Aires, Editorial Futuro, 1950.

Mavridis, Spyros: «Roberto Arlt y el teatro de la crueldad: analogías escénicas en el teatro argentino», en Pavlakis, Pandís Efthimía; Papageorgíou, Anthí y Lugo, Susana (eds.), Estudios y homenajes hispanoamericanos, I, Madrid, Ediciones del Orto, 2012, 97-106.

Pastor, Beatriz: Roberto Arlt y la rebelión alienada, Gaithersburg, Hispamérica, 1980.

Platón: La república, Madrid, Alianza, 1994.

Rela, Walter: «Argumentos renovadores de Roberto Arlt en el teatro argentino moderno», Latin American Theatre Review, 2, 1980, 65-71.

Salles, Nara y Oliveira, Felipe Henrique Monteiro: «El actor con cuerpo diferenciado y la poética de Antonin Artaud», Telón de fondo, 16 (diciembre 2012). Web: http://www.telondefondo.org/numeros-anteriores/numerol6/articulo/ 426/el-actor-con-cuerpo-diferenciado-y-la-poetica-de-antonin-artaud.html (consultada: 29 de septiembre de 2013).

Virmaux, Alain: Antonin Artaud et le theater, Paris, Seghers, 1970. 